\title{
A doutrina de Kant no Brasil
}

(Notas à margem de um estudo de Clovis Bevilaqua)

Miguel Reale

\section{Uma tese de Clovis Bevilaqua}

A "Revista Academica" da Faculdade de Direito do Recife, no numero LIV, dedicado à memória de Clovis Bevilaqua, transcreve um trabalho do insigne jurisconsulto sôbre a doutrina de Kant no Brasil.

Nesse estudo (1), admiravel pela concisão e a limpidez dos conceitos, Crovis Bevilaqua desenvolve uma tese já esboçada em varias passagens de sua obra, dedicando, como era natural, mais atenção às doutrinas filosofico-juridicas, não só em virtude de sua qualidade de jurista, como tambem porque era à sombra acolhedora da Jurisprudência que melhor se desenvolviam as cogitações filosoficas no Brasil até epoca bem recente.

O trabalho do mestre exímio de nosso Direito Civil representa uma discriminação das tendencias fundamentais do pensamento brasileiro, no qual ele jamais pretendeu descobrir originalidades, vendo-o antes, sincera e singelamente,

(1) A doutrina de Kant no Brasil foi escrito por Chovis em 1924, por ocasião das comemorações do segundo centenario do nascimento do filosofo e publicado pela Rev. da Academia Bras. de Letras em 1929, n. 93, pags. 5/14. A Revista pernambucana transcreve-o no n. 371 do hebdomadario "D. Casmurro", que consagrou paginas preciosas à memoria de Cuovis. 
como a historia da repercussão das doutrinas estrangeiras em nosso meio cultural.

Segundo CLovis, "a especulação filosofica pressupõe uma larga e profunda base de meditação nos varios dominios do saber humano, aparecendo ela como uma flor misteriosa e dolente dessa vegetação mental, assim como a poesia é a flor da emotividade. Mas a poesia é flor que se espande em delicadezas de côr e de perfume, desde que esponta a haste na superficie do solo, ao passo que a outra, mais lenta e mais severa, pede os cimos altaneiros para desabrochar." Daí não constituir "desoladora anomalia" a ausencia entre nós de uma escola propria ou de um conceito original de vulto no plano filosofico. (2)

No exame das doutrinas que exerceram assinalada influencia em nossa formação cultural, destaca ele, sucessivamente, depois dos reflexos fugaces do sensualismo de CoNDILLAC, os ecos mais duradouros do espiritualismo em suas diversas feições (Monte Alverne, Ferreira Franģa, Gonghatves de Magalhães, Soriano de Souza, o Visconte de Saboia, Farias Brito), do materialismo (Guedes Cabral, o visconde do Rio Grande, José de Araujo Ribeiro e Vicente de Souza) do monismo (Tobias Barreto, Estelita Tapajoz, Fausto Cardoso, Gruaça Aranha, Almaghio Diniz, Trto livio de Castro) do evolucionismo (Silvio Romero, Artur Orlando e Martins Junior) do positivismo (Teixeira Mendes, Miguel Lemos, Anibal falcão, Souza Brito e Pereira Barreto).

(2) V. o ensaio A repercussão do pensamento filosofico sobre a mentalidade brasileira, inserto no volume Esbogos e fragmentos, Rio, 1899, pgs. 15-44. Identica é a explicação dada por FARIAS Brito: "Para a elaboração de grandes construções filosoficas, originais e fecundas, é indispensavel o concurso do tempo." A filosofia moderna, 1899, 2. a parte da Finalidade do Mundo, pg. 307. E tambem o pensamento do Padre Leonel Franca (Noçóes de Historia da Filosofia, 1940, pg. 289) contestando a afirmação de ToBIAS BARreto de que "o Brasil não tem cabeça filosofica" Cfr Questões Vigentes, pg. 240. Sobre esse assunto v. CRuz Costa; A Filosofia no Brasil, Porto Alegre, 1945, pg. 19 e seg. 
Nessa enumeração, que abrange o nosso desenvolvimento cultural somente até 1922, - época em que, ao par de fecundas agitaçôes politico-sociais, começavam a desabrochar outras tendencias destinadas a dar novo ritmo à nossa cultura, (3) - Bevrlaqua não reserva um lugar para a filosofia de KANT, asseverando mesmo que "o kantismo não fez proselitos assinalaveis entre os nossos talentos mais produtivos"

Será procedente essa afirmação de Cuovis?

O estudo, que está dando motivo a estas observações dedicadas à memoria do egregio jurista-filosofo, - pois não há melhor homenagem a um mestre do que a discussão de suas ideias, - compendia os motivos de não ter o criticismo encontrado adesões mais fortes e dilatadas entre nós, da seguinte forma: a) "quando o Brasil despertou para as especulaçốes filosoficas, já estava vencido o terço do século XIX; a esse tempo, outras correntes de ideias se haviam estabelecido e a que sabiamos de KANT nos vinha através de Cousin, cuja eloquencia nos seduzia; b) depois, quando se deu a volta do pensamento moderno às fontes kantianas, já não era mais o criticismo que se nos apresentava, e sim o

(3) Não cabe aqui o estudo critico-valorativo das novas tendências do pensamento brasileiro, desde aquelas que importaram em uma nova compreensão de Farias Brito, ponto de partida de posições espirituais autônomas, como as de Jakson de Figueiredo, Tasso da Silveira, Tristão de Athayde e Plunio Salgado até às posições dos adeptos do materialismo historico de MARx e ENGELs; do sociologismo cultural (Gilberto Freyre); do neo-positivismo (PonTES DE Mranda) da axiologia nietzscheana; da filosofia fenomenologica, (Euryalo Cannabrava) etc., ao par de desenvolvimentos notaveis de tendencias anteriores, como se vê nas obras de Vicente Licinio Cardoso, Ivan Lins, Laurindo Leão, Azevedo Amaral. Sobre essas novas tendencias, v. Alceu Amoroso Lima - Meditação sobre - mundo moderno; Rio, 1942 e a serie magnifica de seus "Estudos"; Frantando de Olivfira Mota, Compreensão de Farias Brito, Recife, 1943; OLIverra Torres, $O$ positivismo no Brasil, Rio, 1943; as series do Jornal de Critica de Alvaro Lins; Guilherme Francovich Filosofos Brasileños, Buenos Aires, 1943 e Cruz Costa, op. cit. 
aproveitamento de algumas de suas doutrinas por sistemas diferentes; c) finalmente, por alguma cousa deve ter concorrido, para essa inassimilação, o que há de rebarbativo nas exposições do filosofo alemão." (4)

É possivel que a falta de uma integração mais profunda do criticismo entre nossos valores mentais seja devida a motivos outros, alem dos apontados por Bevilaqua, o qual atribue tambem o sucesso de algumas correntes, no Brasil, como a do espiritualismo de Cousın e Jouffroy, à força de sua eloquencia palavrosa, tanto de nosso gosto, ao "quinhão que ele abria à imaginação, ao cismar sem freios, falando tão de perto às nossas tendencias intelectuais, mesmo ao nosso lirismo" (5).

Analogas as razões de exito do positivismo, que, ainda no dizer de Clovis, "resumindo o conjunto vastissimo do saber humano em poucos livros, e impondo os preceitos cientificos com o dogmatismo intransigente com que evangelizam as religiões abluindo maculas de heresias, favoneava a nossa indolencia mental, que prefere os devaneios da imaginação $\mathrm{e}$ as facilidades do dogmatismo às asperezas do estudò e da analise." (6)

Do monismo de HaEckel, mesmo com os enxertos teleológicos de Norré, que Tobias Barreto considerava um oraculo do pensamento da epoca, tomando nuvem por Juno; e do evolucionismo spenceriano, que Silvio Roмero amalgamava com Huxuey, Noiré e Ihering, talvez se possa dizer o mesmo: eram concepções cerradas do universo e da vida, onde tudo parecia adquirir proporção e sentido exatos, deixando nos espiritos, ao par de uma segurança baseada em conhecimentos pretensamente "cientificos e positivos", um sentimento de plenitude e de satisfação, pela correspondencia que pare-

(4) Clovis, art. cit., Rev. Ac. Recife, pg. 176.

(5) CLovis, Esboços e fragmentos, cit. pg. 24.

(6) Cuovis, op. cit., pgs. 25/26. Note-se na agressividade do tom o eco da posição de Silvio Romero em Doutrina contra Doutrina, Rio, 1894, publicado um lustro antes. 
cia evidente entre as conclusões das pesquizas fisico-matemáticas e os conceitos filosóficos ordenados em sistema.

O ecletismo espiritualista o positivismo, o monismo e o evolucionismo, - não obstante possuirem, como todas as correntes filosoficas, germens fecundos de "perplexidade intelectual" e, portanto, elementos suscetiveis de analise profunda e renovada, - foram sistemas que preferimos receber como "algo já feito", traduzido mesmo em ideias definitivamente permeabilizadas e acessiveis, quando não em imagens esteriotipadas, como quem cuida de um adorno que se acresce à cultura, e não de uma força que na cultura se integra como fator dominante.

A doutrina de Kant, no que ela possue de perenemente vital, não se presta a essas recepções faceis, nem pode ser convertida em um conjunto cerrado de principios. $O$ criticismo é antes um metodo, uma atitude ou posição espiritual. E um ponto de partida para a pesquiza criadora; mais uma forma de inquietação e de crise estimativa do que de plenitude e suficiência. Daí poder-se dizer que a presença de KANT, ao menos como motivo de filosofar, constitue um sinal de densidade cultural, como certas roupagens vegetais assinalam as terras ricas de humus. A compreensão de KANT não permite, em verdade, uma atitude ou forma comoda de filosofar sem excessiva filosofia, sem serem empenhadas a fundo as nossas mais subtis capacidades de inteligência em um trabalho perseverante e metódico.

Nem mesmo Clovis fugiu às contingencias da recepção do evolucionismo spenceriano, embora tivesse procurado compor as ideias do filosofo britanico com as de juristas filosofos do porte de Ihering e Hermann Post, as duas forças alienigenas fundamentais de sua formação espiritual. A "luta pela vida" sublimava-se em uma forma nobre de "luta pelo direito".

(7) Referindo-se a Ihering e Hermann Post, a cuja obra dedica ensaios especiais, dizia CLovrs que "entre juristas alienigenas, a eles devemos a ação principal de transformação que tem idọ reti- 
Negando qualquer ressonancia notavel da doutrina de Kanr no Brasil, o saudoso mestre esclarece, de passagem, que o pensamento do filosofo da "Critica da Razão Pura" teria sido, entretanto, objeto de cuidadosos estudos em nossas Faculdades, exercendo mesmo uma influencia indireta através do compendio de Direito Natural de AHrens, geralmente adotado, no qual se expõe a doutrina de Krause, "que representa uma das direções das idéias de Kant, combinadas com as de Spinoza." (8)

Quasi como compensação da verificada ausencia da doutrina de Kant no Brasil, escreve Bevilaqua que há, porém, "algumas paginas na literatura brasileira em honra a KANT que não devem ficar deslembradas", citando dentre outras as de ToBias Barreto que "celebra a volta dos espiritos a KaNT sob o impulso da propria ciencia, divorciada da filosofia depois do desastre do hegelianismo" (9); os estudos do

rando da jurisprudencia essa tomalidade soturna de canto-chão, e esse odor enjoativo de mofo, que afastavam dela a curiosidade ávida dos moços." (Juristas filosofos, Bahia, 1897, pg. 83). Ciovis foi na realidade um ecletico e sinceramente o reconhecia, (Rev. da Ac. de Direito do Recife, vol. cit., pg. 73) mas o nucleo essencial de seu pensamento permaneceu fiel ao espirito da Escola de Recife, contrario a todas as formas de Metafisica. A tal ponto que ele, tão comedido em seus juizos, recusava aos brasileiros, definitivamente "aptidão para subtilezas e argucias metafisicas." (Esboços e fragmentos, cit. pg. 25). A aversão à Metafisica e ao Direito Natural foi uma constante no pensamento do grande jurista, embora lhe parecesisem aceitaveis, até certo ponto, as ideias de STAMMLER sobre o "direito justo". (Cfr. Ciovis, Estudos juridicos, Rio, 1916, pg. 103). Concordava èle com a afirmação de Tóbias BARREto de que "não existe um direito natural, mas pode-se dizer que há uma lei natural do Direito". (Tobias Barreto, Questóes Vigentes, Sergipe, 1926, pg. 125). E tambem a orientação de Silvio Romeno, Ensaios de Filosofia do Direito, 2.a ed., Rio, 1908, II Parte, e, no fundo, a de Pedro Lessa em seu estudo publicado no vol. II desta Revista, sintetizado depois nos Estudos de Filosofia do Direito, Rio, 1916, 2.a ed., pgs. 35 e segs.

(8) Art. cit., pg. 176.

(9) Ver ToBIAs BARreto, Recordações de Kant em Questões

Figentes. loc. cit. 
criticismo kantiano elaborados por FARLAS BRTTO, "a maior vocação filosofica das letras brasileiras" (10); de Pedro LESSA, que apresenta, entretanto, a doutrina "com a intenção de lhes expor os pontos fracos" (11) de José Mendes (12); de Januario GaFFréE, cujo ensaio é a unica monografia nacional dedicada ao sistema criticista (13), com inegaveis simpatias pelo pensador de Koenigsberg.

Conclue Grovis Bevilaquia o seu trabalho dizendo que, em suma, as ideias de KANT não foram das que influiram mais fortemente na marcha do pensamento brasileiro, exercendo apenas a ascendencia propria das grandes correntes que no fundo do conhecimento revelam claridades novas.

O krausismo e a influencia de Kant no Direito patrio A geração de Alvares de Azevedo e João Teodoro.

A tese de Cuovis, que expuzemos com algumas observações criticas, não nos parece de todo aceitavel, pois, além de ter sido esquecido o nome do preclaro LAFAyETTE RoDrI-gues Pereira, - cuja posição de relevo nas letras juridicas é desnecessario encarecer, sendo o representante quasi ortodoxo do pensamento kantiano no Brasil, - deixa na sombra alguns elementos de importancia, especialmente se nos colocarmos segundo o prisma filosofico-juridico que preocupou o antigo mestre do Recife.

(10) Ver Farias Brito, O Mundo como atividade intelectual, Parả, 1905 e $A$ verdacie como regra das ações, Pará, 1905, pg. 61 e segs. e 94 e sgs.

(11) Cf. Pedro Lessa, op. cit., pg. 279 e segs.

(12) Jossé Mendes, op. cit., vol. I.

(13) Januario Lucas Gapfrée - A teoria do conhecimento de Kant, Rio, 1909. Limitando-nos, como fez Clovis, aos dominios da Jurisprudencia, é de toda justiça lembrar o ensaio de João Arruda. sobre Kant em sua Filosofia do Direito, vol I, pgs. 81-110. 
Em primeiro lugar, a referencia a Krause foi demasiado restrita, quando se trata de um filão que, ao menos no que se refere à Faculdade de Direito de S. Paulo, merece maior exame.

Nas comemorações do centenario dos cursos juridicos, fazendo um escorço do pensamento do primeiro seculo de nossa Academia, o Prof. Reynaldo Porchat compreendeu a necessidade de dedicar todo um capitulo a $\mathbb{K}_{\text {ANT, }}$ cujas colocações filosoficas sobre o Direito e a Justiça eram as dominantes no inicio do sec. XIX. (14)

Foi sob o signo das ideias de Kant que tiveram inicio os estudos juridicos no Brasil, onde, entretanto, só chegaram os principios do filosofo, como bem notou Clovis, através de fontes que lhe alteraram a substancia crítica.

Nenhuma doutrina, em verdade, correspondia mais do que a de Kant às aspirações do liberatismo burguês, aos imperativos do individualismo economico que iam processando o abrandamento do radicalismo rousseauniano nos quadiros do "Estado de Direito" segundo os moldes da "liberal-democracia". (15)

Não será exagero dizer-se que a mentalidade de nossos politicos e juristas de então, profundamente liberal e individualista, era em grande parte kantiana e rousseauniana, mesmo sem terem plena e direta consciencia das raizes filosóficas de suas posições doutrinarias. A ideia de liberdade como um "direito inato"; o entendimento da convivencia social como uma limitação reciproca de liberdades; o respeito à pessoa humana como base da justiça e fim da ordem social; o Direito como condicionalidade dos arbitrios, susce-

(14) Rev. da Fac. de Direito de S. Paulo, 1928, vol. XXIV, pgs. $341-347$.

(15) Sôbre o valor politico do kantismo como momento essencial da cultura burguesa, vide nossos trabalhos Formação da Politica Burgueza, S. Paulo, 1934; O Estado Moderno, 3.a ed., S. Paulo, 1935; ensaio $O$ Contratualismo - Posição de Rousseau e Kant publicado, no volume XXIII desta Revista, pgs. $118 / 150$ e Teoria do Direito $e_{\text {; }}$ do Estado, São Paulo, 1940. 
tivel de legitimar o emprego da coação material, eis aí os quatro ponto cardeais da filosofia juridica de KANT, que possibilitaram aos liberais da epoca ascencional dos valores burgueses uma orientação segura nos dominios das ciencias humanas.

Foram essas ideias, pelas quais Kant é ainda de certa forma um prolongamento do jusnaturalismo do seculo XVIII, - foram essas idéias, e não as do criticismo que Kant não elaborou fielmente no plano do Direito, que passaram para as nossas escolas, atravez do krausismo, um kantismo de terceiro grau, visto como já se desprendia de uma derivação, que é a de Fichte e; Schelling.

A Krause estava reservada uma projeção inesperada no mundo hiberico. O fenomeno da ascendencia krausiana, que ainda hoje causa estranheza a certos espiritos, foi quasi que concomitante em Portugal e na Espanha.

Diz-nos o Prof. Cabral de Moncada, que é no ano de 1844 que Krause passa a ser o mentor filosofico das aulas de Coimbra, em virtude da atuação de Vicente Ferrer Neto Paiva, ou Ferrer, como é geralmente mais conhecido. No dizer de Moncada, coube a Ferrer, julgado pelos "emancipados" do naturalismo spenceriano com perseverante ironia, elevar a doutrina filosofico-juridica de Coimbra "à altura, que no seu tempo ela tinha atingido em outros centros de estudo europeu." (16)

Os Elementos de direito natural ou de Filosofia do Direito, de autoria de Ferrer, revelam a intenção de inspirar-se na filosofia de KANT, que "fornecia na primeira metade do seculo a formula mais perfeita do liberalismo politico".

Ereciso notar, porém, que consoante justa observação do atual mestre da Universidade de Coimbra, "não foi a pura filosofia kantiana idealista e critica, que ele foi buscar à Alemanha, mas um sistema de idéias em que um novo e

(16) L. Cabral de Moncada, Subsidios para uma Historia da Filosofia do Direito em Portugal, 2. a ed., Coimbra, 1938, pg. 41. 
tardio jusnaturalismo aparecia mais uma vez combinado com essa filosofia e a de Schelling e então muito em voga: o sistema de Krause. Isto é: não foi o puro criticismo kantiano, mas o sistema de Krause com certos ingredientes de kantismo, interpretado sobretudo pelos seus discipulos 'Ainrens e Tiberghien, que em 1844 substituiu nas aulas de Coimbra a velha filosofia wolfiana de MARTiñ através do ensino de Ferrer." (17)

Foi ainda em 1844 que apareceu a tradução portuguesa do "Cours de droit naturel ou de Philosophie du droit" de Henri Ahrens, que, juntamente com as obras de Tiberghien, constituiu a fonte primordial de divulgação do pensamento krauseano, forma ecletica do idealismo alemão ajustado às exigencias espiritualistas e romanticas da época.

Foi tambem em 1844 que SANZ del Rio seguiu para a Alemanha afim de estudar Filosofia, sendo induzido por Tiberghien e Ahrens a conhecer o sistema de Krause, que iria divulgar em suas obras, preparando o ambiente cultural de seu discipulo, Francisco Giner de los Rios, o maior representante da doutrina no mundo hibérico. (18)

Apreciando a repercussão de Krause na Espanha, o ilustre Recasens Siches traça considerações plenamente aplicaveis ao meio luso-brasileiro:

"Não é estritamente Krause, observa, no que ele tem de rigorosamente original na historia dos sistemas, que obtem exito tão intenso e dilatado na Espanha. É antes o complexo total de seu pensamento, que compreende uma especie de ensaio de sintese harmonica dos principais ingredientes da moderna filosofia alemã, na qual pululam KaNT e Fichte, Shelling e Hegel; que traz em seu seio um patos liberal

(17) L. Cabral de Moncada, op. cit., p. 43.

(18) Sobre o "krausismo na Espanha, ver Recasens Siches “Adiciones” à Filosofia del Derecho de DeL Vecchio, vol. II, pgs. 271-288 e a bibliografia indicada por Ferrater Mora em seu Dicionario Filosofico, México, 1941. 
e democratico e, ao mesmo tempo, um sentido organico da Sociedade e do Estado; que entranha uma delicada atitude profundamente espiritual e religiosa ante o mundo e a vida; e que encarna um aspecto romantico, com o qual se sintonizou, naturalmente, a consciência espanhola daquela época, predisposta àquela maneira de sentir." (19)

Pois bem, se lembrarmos que o compendio de Ferrer foi por muito tempo o livro de cabeceira de nossos estudiosos de Direito Natural; se pensarmos na influencia poderosa do "Curso" de Ahrens, que ainda hoje se lê com positivo benefício; poder-se-á avaliar a influencia decisiva que o krausismo exerceu em nosso ambiente politico e juridico, modelando a mentalidade dos liberais do Imperio.

Na Faculdade de Direito de S. Paulo essa ascendencia cresce de ponto, especialmente quando em um mesmo sentido se conjugam os ensinamentos de Galvão Bueno no "Curso Anexo", autor de umas "Noções de Filosofia" publicadas em 1877, sob inspiração de Trbenghten, com as aulas do Prof. Joño Teodoro Xavier, cuja obra "Teoria Transcendental do Direito", impressa em 1876, compendia os principios fundamentais do "racionalismo harmonico" de Krause, com frequentes referencias à doutrina de KaNT. (20)

Referindo-se a êsse momento da história cultural da Academia, o Prof. João 'Arruda, no citado estudo sôbre os princípios jurídicos de KANT, assim escreve:

"A escola de KANT representou, mesmo em São Paulo, papel importantisimo. Em tempos antigos, segundo fui in-

(19) Recasenis Siches, op. cit., pg. 285-6. Ferpater Mora diz mesmo que, abstração feita dos pressupostos do filosofo alemão, o krausismo converteu-se na Espanha em um "movimento de republicanismo liberal." Liberal foi tambem, como nota Moncada, a posição de FErRer, intimamente identificado com a orientação politica de Alexandre Herculano (loc. cit.)

(20) Sobre a doutrina de Krause, tal como era recebida no meio brasileiro, ver José Mendes, Ensaios de Filosofia do Direito, vol. I, ensaio VI. 
formado, houve uma aula destinada à vulgarização da doutrina de KANT, e creio que era regida por uma das mais legitimas glorias brasileiras".

"Essas mesmas doutrinas influiram profundamente nos compendios de Ferrer e nas exposições de Dias Ferreira, que foram os oraculos do Direito Natural nesta Academia, até a epoca em que o meu mestre JoÃo TEODORo adotou para compendio os seus "Principios Transcendentais do Direito" vasados nos moldes de Krause, embora com grandes modificações."

A historia da juventude academica de nossa Faculdade apresenta no seculo dezenove dois momentos culminantes. Um deles é assinalado por fortes pendores filosoficos; o outro, por um profundo sentido de renovação politica e social, Eram ambos animados, porém, de idêntico sopro essencial de arte e poesia. Expressões de duas gerações seduzidas por ideais distintos são, respectivamente, Alvares de Azevedo e Castro Alves. Se o cantor dos escravos marca a tendencia politico-social que iria se tornar a dominante no ritmo existencial das Arcadas, o poeta da "Lira dos Vinte Anos" representa uma afirmação singular em nossa cultura, pela consciência plena dos valores da inteligência e do espirito.

Estranha geração aquela que, no meado do seculo passado, agita a pacata capital de provincia com as suas atitudes integradas na vivência romantica da época! Talvez ainda não se tenha dado o devido relevo ao "sentido cultural" daquele periodo, no qual a expressão poetica, por ser a dominante, atrae, quando não absorve, a curiosidade dos pesquizadores.

Quem volve, entretanto, a atenção para aquela epoca, em busca de elementos caracteristicos de nosso desenvolvimento cultural, nela encontra dados de alto interesse tambem para valores filosóficos, já tendo sido observada que, apezar da tentada transplantação da cosmovisão estética de Byron, Musset ou Leopardi para terras americanas, é então que mais se acentua a nossa emancipação espiritual. 
A era academica de Alvares de Azevedo distingue-se por um impeto de pesquiza, de assimilação de valores alienigenas e de criação propria. A figura do poeta de vinte anos, macerado pelas vigilias, resume o espirito de uma juventude, falha de disciplina metodica, mas devorada pelo desejo de saber. Podemos mesmo afirmar que Alvares de AzEvedo é a expressão viva de uma cultura adolescente.

Não haverá, por certo, nessa geração academica dois temperamentos tão dispares como o lirico Alvares de Azevedo e o comedido jurisconsulto Lafayetre Rodrigues Pereira. Pois bem, ambos não divergem, nos bancos academicos, sobre a missão que viam incumbir aos moços. Em seu estilo nervoso, que revela a sua permanente tensão espiritual, Alvares DE AzEvedo contrapõe o sec. XIX ao seculo da Revolução: "O seculo pasado fôra a sagração da soberania popular: o seculo atual foi o reconhecimento de outra soberania ainda mais bela, porque, emanada daquela, desenvolvera-se aos resplendores da Ciencia - a soberania das inteligencias". (20-a)

Identico é o sentido da oração que o futuro civilista profere, poucos anos depois, transferindo a presidencia da famosa sociedade "Ensaio Filosofico Paulistano": "Como preparar-se para tão alta missão, indagava ele, como robustecer-se para sustentar em seus ombros um povo tão forte? Oh - só pela cultura da inteligencia e do coração, pela constancia do estudo das ciencias que estendem os dominios do espirito (.) Com os olhos, pois, fitos nos grandes destinos. da Patria e na missão nobre e elevada da mocidade de hoje - estudemos; não frustremos por um desleixo condenavel as mais caras esperanças de nosso país. Ainda uma vez, estudemos." (20-b)

(20-a) Alvares de Azevedo, Discurso de 14 de agosto de 1849 em "Obras Completas", vol. III, pg. 41.

(20-b) Lafayette R. Pereira, Discurso inserto na "Revista Mensal do Ensino Filosofico Paulistano" de 30 de junho de 1857. 
Bern poucas vezes uma geração de estudantes terá tido tauta fé nos valores da inteligencia ou tão alto sentimento dos deveres da cultura.

A epoca era dominada pelo ecletismo de Cousin, mas o espiritualismo acomodado do pensador francês não satisfazia a todos os moços, havendo aqueles que, como Alvares DE AzEvEDo, preferia "embeber-se no transcendentalismo alemão - Kant, Fichte, no idealismo mais puro e vaporoso, reduzindo o panteismo de SpINoza e a visão em Deus de Malebranche ao egotismo de Fichte e HeGel", proclamando serem a "filosofia e a poesia os dois grandes caminhos das Nações, as grandes bossas onde se lê a progresso ao craneo popular". Sustentava ele a necessidade de uma "filosofia brasileira do sec. XIX", como "sintese de um povo, como a querem Pedro Leroux e Groberti", e "não : uma ciencia fragmentaria e parasita do passado, palida copia do que foi, como o entendeu o ecletismo de Cousrn." (20-c)

Essas palavras não valem, por certo, como um traçado claro de novos rumos, que fôra impossivel em um jovem de 20 anos, mas revela um estado de espirito, uma consciencia comum de querer que fazia surgir, na nevoenta capital de Piratininga, varias entidades academicas, onde se discutia livre e corajosamente sobre Filosofia e Historia, Arte e Direito, publicando-se revistas e jornais, em cujas colunas se destacavam nomes que iriam se inscrever depois nos fastos de nossa Historia, como os de Tavares Bastos, Teoflo Ottoni, Gaspar Silveira Martins, lafayette Rodrigues Pereira, José Bonifacio, o Moço, João Teodoro, Paylino José SoAres de Souza e outros de igual porte.

Além da já lembrada associação academica, "Ensaio Filosofico", que mantinha uma "Revista Mensal", merecem recordação o "Ateneu Paulistano", que publicava os "Ensaios Literarios", a "Arcadia Paulistana", o "Culto à Ciência", o

(20-c) Alvares de Azevedo. Discurso proferido em 1850, na sessão de instalação da sociedade academica "Ensaio Filosofico" op. cit., vol. III, pg. 59 e 'segs. 
"Club Cientifico", o "Recreio Instrutivo", havendo varias publicações destinadas à cultura geral, como "O Acayaba", o "Guayaná" e a "Revista da Associação Tributo às Letras". Quem quer que se proponha penetrar nas matrizes de nossa - formação cultural, com a sensibilidade aguda de um Dilthey ou de um Groetruysen, não poderá deixar de examinar essas publicações academicas, pois a historia filosofica de um povo não se faz apenas à luz dos tratados de seus expoentes maximos. Representam tais escritos academicos um escrinio precioso aos olhos de um analista de nossa historia espiritual. A busca de motivos poeticos nacionais, sob o influxo do Romantismo, casava-se a um sentido universalista da cultura, de maneira que aquela geração, ao mesmo tempo que clamava pela "nacionalização do direito", por ser a palavra "nacionalidade", no dizer de um colaborador da "Revista Mensal", "a palavra magica que ocupa o pensamento calmo e severo do homem de Estado, que faz vibrar a voz do professor, que eletriza o coração dos mancebos", (20-d) rendia tambem culto entusiastico a outra palavra magica, “civilização", que aparece em um editorial de "O Acayaba", de abril de 1858, como "a estatua viva da humanidade, cinzelada pelo esmero dos seculos".

Cultura e nacionalidade, eram as ideias força que faziam vibrar o irrequieto Alvares de Azevedo e seus contemporaneos, seduzidos pelo ideal de uma filosofia e uma poesia nacionais, "irmãs gemeas da civilização", "varias em sua unidade, unas em sua variedade." (20-e)

A doutrina de KANT encontrou ressonancia no meio cultural paulista, assim como o proprio Hegel teve seguidores em materia estetica, como se pode ver na Revista Mensal do "Ensaio Filosofico". Limitando-nos ao campo da filosofia juridica, lembramos uma das afirmativas do então acade-

(20-d) Ver Rev. cit., Julho de 1859.

(20-e) Alvares de Ażevedo - Obras Completas - vol. III, pgs. 57 e segs. 
mico A. J. DE MAcedo SoAres, na qualidade de relator da Comissão de Ciencias Sociais do "Ensino Filosofico":

"O traço o mais caracteristico do direito, é aquele que foi precisado por KANT; o direito é uma linha divisoria entre as esferas das liberdades individuais: por isso não pode haver direito senão na sociedade, no comercio ativo dos homens, por isso todo direito é exterior."

Já recordamos o nome de João TeOdono como um dos mentores da associação que teve Alvares de Azevedo como patrono. Foi, pois, em um meio de intensa atividade cultural que o autor da "Teoria Transcendental do Direito" afeiçoou o seu espirito aos problemas de filosofia. O livro de ЈоÁо Теороно, onde observações das mais sagazes, (como, por exemplo, as dedicadas à "intencionalidade" e a "exigibilidade" do Direito)' se justapõem a um conglomerado de fatos historicos e mitologicos nem sempre invocados a proposito, representa uma tentativa de superar o individualismo juridico caracteristico da doutrina de KANT. Di-lo o Autor claramente no prefacio da obra, condenando o compendio de Ferrer, até então seguido nos cursos:

“A' formula originaria, negativa $\mathrm{e}$ individualista das doutrinas de Cousin e Kant, constitue o espirito geral de sua obra (referia-se ao compendio do mestre lusitano), ao mesmo tempo que exalta e tece ele panegiricos pomposos às teorias harmonicas de Ahrens e de Krause.

"Nossas opiniões, ampliando a dos ultimos escritores, prendem-se, pela afinidade, mais a estes do que àqueles." (20-f)

Na realidade, Joño TEODono não revela ter assimilado a essencia do "criticismo". Entendendo o Direito Natural como

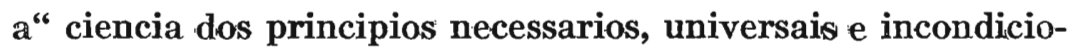
nais da Justiça" trata de questões particulares e acidentais a que dá grande relevo. Depois de expor as ideias mestras do "sistema de KANT", Joño TEODORO esclarece os motivos de

(20-f) JoÃo TEODORo, “Teoria Transcendental do Direito", 1876, pagina IX. 
sua divergencia, especialmente, porque não aceita a definição do fillosofo alemão que se satisfaz com o aspecto negativo do Direito, a delimitação reciproca das liberdades. $\quad$ t que no entender de Krause, cujas doutrinas adota com alguns desenvolvimentos, compete à ordem juridica assegurar as "condições da existencia e desenvolvimento para a vida humana", de maneira que a formula do direito não se limite a traçar uma linha divisoria entre as atividades livres, sendo "antes de tudo um principio de ação e de coperação reciproca; aproxima a especie humana, estreita os vinculos sociais, cimenta e fecunda o espirito de sociabilidade." (20-g)

Fundado nesses principios, o antigo mestre de Direito Natural proclamava "os direitos de existencia e de ocupação produtiva dos homens", chegando a declarar que a teoria do socialismo, segundo a qual é dever do Estado a "coadjuvação efetiva e positiva de meios imprescindiveis à vida $e$ ao trabalho, é indisputavelmente verdadeira."

As peremptorias afirmações de JoÃo TEodono, reconhecendo não só o direito como coordenação de liberdades, mas tambem o direito como "conjunto de condições positivas à vida e trabalho", asseguram-lhe o lugar de precursor brasileiro do chamado "Direito Social" ou "Direito do Trabalho", incluindo-o entre os primeiros a apontar entre nós os rumos da socialização ou humanização do Direito. (20-h)

E com Jỗo TEODono que o krausismo apresenta no Brasil raros lampejos de desenvolvimento autoriomo, ao passo que

(20-g) Jỗo TEONORO, op. cit., pg. 326.

(20-h) Joño TEODono, op. cit., pg. 333. Este mestre, que como governador da provincia de São Paulo, revelou grandes qualidades realizadoras, entendia o socialismo em sentido amplo, dando uma definição que merece ser lembrada: "As doutrinas șocialistas são aquelas que, assinando ao Estado, como fim especial, o fornecimento obrigatorio e rigoroso de condições positivas à vida e trabalho de seus membros, organizam nele instituições societarias, ou de outra natureza, segundo quais constante e sistematicamente essas condições ou cooperações positivas devem ser prestadas." 
em outros autores se transforma em um ecletismo impreciso, como o que se depreende desta profissão de fé de SÁ E Benevides: "Eu professo os principios da escola doutrinaria de Krause e dos catolicos (sic), que ensinam que tais instituições (a familia e o Estado) são permanentes e que têm a sua origem em Deus, como causa primaria." (20-i)

Não se podia distanciar-se mais de Kant, pelas mãos de um de seus continuadores.

Como se vê, a doutrina de Krause, - que apesar de seu ecletismo, é rica de motivos para seria indagação filosofica, como o demonstrou recentemente GuRvitch, apontando-a como uma das correntes precursoras do "direito social" contemporaneo (22), - estiolou-se nas mãos de varios de nossos juristas, convertendo-se em mero lugar comum espiritualista.

(20-i) Sá e Benevides, Filosofia Elementar do Direito Publico, interno, temporal e universal, São Paulo, 1887, pg. 9. Nas "Postilas de Direito Natural" de Sá e Benevides, litografadas em 1880, encontram-se graves restrições à doutrina de Krause, considerado, aliás, filosofo inferior a seu discipulo Tiberghien. Diz BENEvides que não se concilia com o "Syllabus" o racionalismo paneenteista de Krause e seus continuadores. Mas o "racionalismo harmonico" é considerado, em certos pontos, menos perigoso que o de Wolf ou de Cousin. Dai a tentativa de concilação com os ensinamentos de RoSmini, TAParelli etc. Não se pode negar que o ecletismo racionalista favoreceu uma atitude dogmatico-juridica de relativo equilibrio, na qual os principios gerais inspirados em Ahrens, Bérme ou Jouffroy se casavam às conquistas mais atuais da Dogmatica franceza e alemã, com apoio em Savigny, Hugo, Zachariae, Mackeldey, Thibaut, etc. além dos mestres lusitanos como Melo Freire e Lobão. O Curso de Direito Civil do Conselheiro Ribas é nesse passo significativo, marcando um momento de relevo na historia da civilistica brasileira do seculo passado.

(22) Ver Gunvitch, L'idée du droit social. Paris, 1932, pgs. 443-470. Vimos que, no caso de Joño TвоDоRo, pode-se fazer igual afirmação. 
A sua influência valeu mais como um estado geral de espirito, ligado a atitudes politico-sociais, do que como consciencia filosofica especial. Por seu intermedio, o kantismo, que chegou até certas inteligencias, tornava-se uma doutrina desvitalizada porque essencialmente "a-critica".

\section{A influeneia de Kant através da dogmatica juridica - Posição de Teixeira de Freitas.}

De duas ordens pode ser a influência de Kant no dominio da Jurisprudencia. Ou ela se opera através da compreensão de sua doutrina critica; ou se verifica em virtude de seus escritos especiais sôbre o Direito. Por outras palavras, KANT exerce um influxo diverso, quer se apreenda o seu pensamento nas fontes puras das tres "Criticas", e notadamente, na "Critica da Razão Pura"; quer se aceitem apenas os elementos doutrinarios de sua obra especialmente destinada ao Direito, os "Principios metafisicos da doutrina do Direito", publicada em fins de 1796 , aos 73 anos de idade.

E hoje ponto pacifico que o filosofo de Koenigsberg não foi rigorosamente "kantista", ou seja, rigorosamente fiel ao seu criticismo transcendental, quando volveu sua atenção para o problema juridico, apesar de neste dominio ter realizado inovações relevantes, como lembramos em outro trabalho publicado nesta revista. (23)

A poderosa influencia do kantismo (note-se que nos referimos às conclusões da filosofia critica, e não à obra especial dedicada a Direito) nos trabalhos de Hugo e de Thibaut é fato hoje perfeitamente esclarecido. Aliás, quando Hugo, no seu Tratado de direito natural como filosofia do direito positivo, reclamou uma nova metodologia para o estudo do Direito, aplicando os principios da critica kantiana, Fries, com muito acerto, notou que a sua atitude era "de vol. XXIII.

(23) O Contratualismo, posiçẫo de Rousseau e Kant, cit., 1942, 
um kantismo mais consequente do que o do próprio KanT", o qual, em verdade, não se mantivera "consequente" no estudo do Direito. (24)

A Clovis Bevilaqua não escapou essa repercussão, tendo observado que "não é somente entre os filosofos que os Elementos Metafisicos da teoria 'do direito, ecoaram. FeuErBACH, o notavel reformador do direito criminal na Alemanha, é discipulo de Kant; Zachariae, o correto civilista popularizado nos paises latinos por AUbry e RAU, é discipulo de Kant; assim Hugo, Savigny e outros muitos."

Savigny, como lembra Solari, foi um apaixonado cultor de filosofia só na primeira fase de sua atividade cientifica, revelando o seu "Tratado da posse no direito romano", tantas vezes invocado pelos civilistas patrios, profunda influencia de KANT. A presença kantiana revela-se, por exemplo, na determinação generica e especifica do "animus", com a afirmação do predominio do elemento subjetivo sobre os elementos externos objetivos, conforme uma das caracteristicas do subjetivismo juridico do filosofo de Koenigsberg.

Enquanto na tradição romana o animus era considerado a apreensão intelectual da cousa, daí resultando uma relação intelectual mais do que volitiva, SAvigny formou um conceito bem diverso do lanimus em relação ao corpus, entendendo-o sobretudo como uma determinação do querer, como Bestrzwilce, dë conformidade com a tendência à subjetivação das relações juridicas privadas de molde kantiano. (25)

(24) Cfr. Renato Treves, Il problema dell'esperienza giuridica e la filosofia dell'immıanenza di G. Shuppe, Milão, 1938, pg. 97 e segs., e Solari, Filosiofia del Diritto Privato, t. II, (Storicismo e Diritto Privato), Turim, 1940, pgs. 15 e segs.

(25) Solari, Filosofia del diritto privato, cit. rol. II, pgs. 75-76. O mesmo autor pondera que outro dos principios do kantismo acolhido pela Escola Historica, ou melhor, per HwGo e $\mathrm{S}_{\mathrm{A} \text { - }}$ VIGNY, foi o da "autonomia da realidade empirica e o dogma do relativismo do saber fenomenico" (op. cit. pg. 88). Não só o historicismo, como o positivismo juridico, apoiaram-se naqueles pos- 
$\mathrm{Na}$ realidade, a doutrina de KANT vislumbra-se nas matrizes mesmas do pensamento de Savigny, desde a sua concepção do Direito, - como regra que determina os limites ideais da atividade livre e garantida de cada individuo no seio de uma convivencia de "pessoas", ou seja, de seres dotados de igual natureza e liberdade, - até à sua doutrina da relação jurídica, fulcro das pesquizas ulteriores da Ciência do Direito, como uma relação de pessoa a pessoa determinada por uma regra de Direito, tendo, assim, um elemento material e um elemento formal discriminados segundo pressupostos da gnoseologia kantista. (25-a)

Não resta duvida, entretanto, que, não obstante o alargamento do "metodo historico" em uma visão total dos fenomenos juridicos ("historicismo") e a existencia inegavel de pressupostos kantianos em sua doutrina, o excelso romanista timbra em ser jurisconsulto, cultor da Jurisprudencia, não da Filosofia. Savigny tornou-se um jurista puro, o modelo dos juristas do seculo, preocupado com a estruturação dogmatica de seu mundo de normas, apoiado sobre o embasamento etico da moral cristã recebida como uma condição ou como um fim de juridicidade, mas sem constituir objeto de indagações especificas. (26)

É essa tambem a posição típica do mais original de nossos juristas, Terxeira de Freitas, que foi discipulo emerito de SAvigny, a quem ele se referia quasi sempre em termos

tulados kantiano, para excluir qualquer cogitação sobre o Direito Natural por ser meta-empirica ou meta-cientifica. Esse, pode-se dizer que foi um dado "criticista" que se tornou patrimonio comum la familia dos juristas nacionais e estrangeiros no seculo passado.

(25-a) Cfr. Savigny, Sistema, ob. cit., vol. I, pg. 334 e segs. Ver Fritz Schreier, Concepto y formas fundamentales del derecho, Buenos Aires, pg. 70.

(26) "O fim geral de todo o Direito, - afirma SAvigny, que jamais elaborou o "historicismo" como sistema ou momento de um sistema filosofico-juridico, enquadrando-o em uma visão universal — pode reconduzir-se simplesmente à destinação etica da natureza humana, tal como esta nos é exposta na moral cristã." Ver Sistema del Diritto Romano attuale, trad. Scialoja, I, § 15 pgs. 74-75. 
encomiasticos, considerando-o a "primeira autoridade nestas materias", ou lembrando "a suprema autoridade do admiravel escritor que tantas vezes havemos invocado." O grande Terxeira de Freitas estava integrado na dogmatica da Escola Historica, embora conservando uma autonomia de vistas que lhe possibilitou antecipar conclusões que ainda hoje são "novidades" no mundo juridico. O metodo antigo estava quasi banido das escolas, dizia ele, graças à 'Alemanha, “o país da meditação, onde a Ciencia do Direito, associando-se à historia e à filosofia, tem alcançado os mais brilhantes triunfos. (27)

Dotado de admiravel dominio da "ratio juris" e das fontes historicas dos institutos, ninguem estava melhor apareThado do que ele para lançar as bases de nosso Direito, com plena consciencia de que o Direito Positivo não é o produto de "um falso Direito Natural", superior, mas algo "sobre o qual o tempo, os costumes, o genio prarticular dos diferentes povos (note-se aqui o conceito savignyano de Volksgeist), o estado mais ou menos avançado da civilização, e sobretudo a forma da organização politica e social exercem a mais profunda influencia." (28)

Com a mais rigorosa consciencia das exigencias logicodogmaticas ou tecnico-juridicas da Jurisprudência, a ponto de afirmar que "o sistema inteiro de um Código depende muitas vezes de uma só disposição", Teixeira de Freitas foi um adversario sereno do Direito Natural tal como o idealizavam os racionalistas, não podendo compreender como, em face da lei positiva, fosse possivel distinguir "direitos civis mais naturais e menos civis, de outros direitos menos naturais, e mais civis." (29)

(27) V. "Introdução" à Consolidação das Lèis Civis, 3.a ed., 1876, pgs. LII, CXLIX, CLV.

(28) V. Introdução, pgs. LIX, LXXXVII, CXXXIII.

(29) Introdução, loc. cit. Como Savigny, tambem Teixeira dE Freitas tem a noção de que o Direịto Positiṿo é um "processus" 
Essa posição de Teixeira de Freitas corresponde a uma atitude espiritual de raizes kantianas, pois foi o criticista Gustav Hugo o iniciador do movimento que reduziu a Filosofia do Direito à Filosofia do Direito Positivo. Nessa corrente, com o justo sacrificio de um Direito Natural, ideal e. arquetipico, sacrificaram-se tambem elementos axiologicos de suma importancia e inseparaveis da experiencia juridica. Não se soube distinguir o que havia de morto e de vivo na Escola do Direito Natural.

Nesse ponto, nessa auto-suficiencia da teoria do conhecimento juridico, com exclusão de valores estimativos, banidos sob a denominação generica de Direito Natural, observa-se, como no positivismo e no historicismo em geral, uma das notas do pensamento kantiano destinadas a grande exito, com consequencias que jamais poderiam ser aceitas pelo ético da "Critica da Razão Pura."

Para sermos mais precisos, convem notar que TeixeIra DE Freitas, pagando tributo às doutrinas então dominantes, ainda se refere a um Direito Natural como "coleção de normas divinas ministradas pela Filosofia do Direito", mas, logo a seguir, obedecendo à sua orientação positiva, observa que, em varios casos, "as investigações da Filosofia do Direito nada servem para as aplicações. Toda a especulação metafisica, de que não resulte um bem pratico, não tem para nós valor algum." (29-a)

Uma cousa, continua êle, é investigar o direito do ponto de vista de um tipo ideal, para com ele aferir as instituições e legislações dos povos; e outra cousa, observar analiti-

no sentido de uma perfectibilidade etica, havendo um "direito geral" inerente à realidade juridica especifica: "o Direito Positivo, afirma ele, é transitorio, progressivo, até que afinal, pelo bem relativo, atinge o bem absoluto da equidade" (loc. cit., com. ao art. 395 ).

(29-a) Tenxeira de Freitas; Nova Apostila à censura do Sr. Alberto de Morais Carvalho sobre o projeto do codigo civil português, Rio, 1859, pg. 47.

(29-b) Teixeira de Freitas, Apostila loc. cit., pg. 47. 
camente as relações juridicas, que essas legislações regem, para distingui-las uma das outras e classifica-las. (29-b)

É na Apostila dedicada ao projeto do codigo civil português que se revela bem o autentico pensamento de Terxerra DE Freitas, contrario ao Direito Natural tal como era concebido pelos racionalistas da epoca. Reconhece ele, entretanto, como um kantista melhor não o poderia fazer, os elementos logicos "a priori" do direito, que condicionam à experiencia juridica :

"Aquilo que é natural, aquilo que é necessario e conveniente para coexistencia dos homens, coexistencia mantida a priori pela noção eterna do direito, e a posteriori pelos regulamentos da lei escrita, manifesta-se desde logo na vida dos povos, confirma-se pela historia das instituições juridicas, e pela observação de seu desenvolvimento progressivo." (29-c)

Essa distinção entre a noção do Direito, que mantem "a priori" a coexistencia dos homens, e os regulamentos da lei escrita que surgem "a posteriori", encontra um antecedente em Savigny e, na realidade, remonta ao citado Gustavo Hugo.

Dess'arte, embora avesso por indole ao que denominava a "região aerea" das puras cogitações filosofico-juridicas, o nosso Teixeira de Freitas subentendia toda uma atitude critico-valorativa que estava em consonancia com o pensar de seu tempo.

o "neo-criticismo" da Escola do Recife - Kant visto por Tobias Barreto e Silvio Romero

Se através dos krausistas algumas ideias de KANT, mais ligadas à sua herança jusnaturalista, chegaram até nós, fatos de mais graves consequencias verificar-se-iam com a tentativa de Tobias Barreto de conciliar Haeckel e o filosofo da "Critica da Razão Pratica".

(29-c) Teixeira de Freitas, Apostila loc. cit., pg. 189. 
No já citado trabalho intitulado "Recordações de KANT", Tobias refere-se ao filosiofo alemão com indisfarçavel entusiasmo. Segundo Artur Orlando, que escreve o prefacio de "Questões Vigentes", é aquele o mais importante dos trabalhos filosoficos de ToBias, não só pela justa critica da filosofia francesa e especialmente do positivismo de 'Augusto Сомте, como pela "reabilitação da metafisica de KaNT". Sendo ainda um trabalho que, no dizer de Silvio Romero, representou "a profissão de fé ultima do pensador sergipano", (V! o prefacio a "Estudos Alemães"), é deveras significativa a defesa que Toblas Barreto, com o seu costumeiro ardor, faz do mestre do criticismo.

Revela ele o seu acordo com KANT ao conceber a Metafísica, "no bom sentido da expressão", como "teoria do connhecimento" (eine Wissenschaft von den Grenzen der menschlichen Vernunft) e, invocados os exemplos de E. HarTMANN, Norké e SPIR, manifesta a sua crença na filosofia do futuro que deveria ser de novo uma filosofia critica. Por aí se vê até que ponto a doutrina de Kant teve ascendencia sobre o espirito de nosso grande agitador de ideias.

- "O kantismo em sua feição nova, abeberado do pessimismo tentador de Schopenhauer, - escrevera Clovis BeviLAQUA em estudo anterior, - condimentado pelo idealismo cetico de LANGe e Hume, e combinado com o transformismo darwinico pelos esforços de NoIrÉ, teve no Brasil quem lhe consagrasse a elevada potencia de seu engenho e as vibrações, muitas vezes asperas, do seu temperamento de lutador. Foi Tobias Barreto, cujo merecimento como renovador da ciencia juridica entre nós, não deve atabafar o seu valor como ensaista filosofante dos mais conspicuos." (30)

(30) Cuovis, Esbogos e fragmentos, cit., pgss. 35-36. Em outro de seus livros (Juristas filosofos, cit., pg. 23) escreve Ciovis que "ToBIas se utiliza dos trabalhos de Hazckrz e NoIrḱ, verificados pelo criticismo kantiano (sic), e, algumas vezes, remodelando as doutrinas de Ihering e Hrrmann Post, as quais ele fundia no poderoso cadinho de sua inteligencia superior." 
Dificilmente se poderia conceber maior confusão, mais grave perda do sentido essencial das doutrinas. Mais uma vez, KANT ia passar pelas torturas das combinações mais imprevistas. De Comte passa Tobias Barreto para Kant; deste para HAEcKEL, julgando porém encontrar na filosofia kantiana "os elementos necessarios à correção do sistema haeckeliano", inclinando-se, pois, nas pegadas de Niorké, mediocre filosofo alemão que o deslumbrava, na direção de um monismo teleologico ou filosofico.

KANT integrava-se, assim, bem ou mal, no pensamento de Tobias Barreto, que, adotando o monismo haeckeliano, salvaguardava, entretanto, os principios de finalidade e liberdade, entendida esta como "a capacidade que tem o homem de realizar um plano que ele mesmo se propõe." (32)

Não é este o lugar para fazer a critica das ideias de Tobias Barreto, a quem se não podem negar intuições gemiais, desligadas do quadro arrogante de seu precario "sistema". O que desejamos mostrar é que não é possivel excluir sumariamente KANT da filosofia brasileira sem se excluir a contribuição do "monismo teleológico" do fundador da chamada "Escola de Recife", que admirava a filosofia transcedental, sem jamais ter penetrado no significado autentico das "Criticas" kantianas.

Até mesmo quando os discipulos de Tobias Barreto se inclinaram, com Silvio Romero e Clovis Beviladua, para os valores do evolucionismo spenceriano, ainda cuidaram de ver em suas doutrinas uma conciliação entre o filosofo dos "Primeiros principios" e o da "Critica do Juizo"

E o que examinaremos a seguir, para depois apreciarmos as criticas mordazes, mas justas, do Conselheiro LAFAYETE a certas afirmações do critiço desabusado do Recife.

(31) Cf. Hermes Lima, Tobias Barreto, São Paulo, 1939, pgs. 121/128. Vide especialmente pgs. 36 e segs. de "Questões Vigentes". Ed. do Estado de Sergipe, 1926.

(32) Tobias BarReto, v. Questões vigentes, cit. e Estudos de Direito, passim. 
Tobias Barreto manteve, até o fim de seu agitado drama intelectual, grande apego a certas posições kantianas.

Querendo acompanhar HAEckel, tido como a maxima expressão das conquistas cientificas do seculo, mas não desejando se afastar de KANT, o pensador sergipano, em cujo espirito a doutrina finalistica de IHERING exerceu a mais poderosa influencia, preferiu uma linha de conciliação, uma especie de resultante de forças, parecendo-lhe encontrá-la na doutrina de Norré.

Essa composição implicava, desde logo, em uma dificuldade essencial, cuja solução é a caracteristica e a fraqueza do "monismo teleológico". Como conciliar uma concepção monistica do Universo com a ideia de fim? Como aliar a liberdade dos fins a uma teoria de causação universal?

ToBias julgou encontrar em Kant a chave das respostas; em KANT que ele não podia admitị fosse apresentado como um dualista.

Contraditando HaEckel, que incluira o filosofo alemão entre os dualistas, o nosso ToBias protesta com veemencia:

"Esta condenação do grande filosofo (a tanto importaria o juizo de HAEckel), relegado para o meio dos dualistas e teólogos, em nome do monismo, quando o monismo, pelo orgão de NoIré, se confessa ligado, por mais de um laço, à filosofia de KaNT; quando o monismo, que não é um principio constitutivo, mas um principio regulador, quasi diria um principio arquitetonico do pensamento filosofico moderno, assenta em bases kantescas, - esta condenação do grande filosofo, repito, devia naturalmente provocar a impugnação." (33)

Refere-se, então, o autor de "Filosofia e Critica" ao trabalho de Ed. von Hartmann, Wahrheit und Irrtum im Darwinismus, no qual estaria demonstrado, à luz da "Kritik der Urtheilskraft" que "muito ao envez de ser KANT um dualista, firmou êle a doutrina de que a explicação mecanica

(33) Tobias Barreto, Questões Vigentes, 1926, pg. 46. 
e a explicação teleologica dos fenomenos naturais representam momentos diversos de uma unidade superior." (34)

ToBias concorda com essa conclusão e, buscando elementos na propria "Critica da Razão Pura", julga ter demonstrado que KaNT é de fato um monista, um monista que veria entre a causação mecanica e a finalidade apenas uma questão de grau, mais ou menos consoante a explicação de Norré que via um "resto inexplicavel" (devido ao sentimento) em todo fenomeno suscetivel de explicação causal (em razão do movimento).

"Entre o resto, de que fala KANT, e este de que fala NoIRÉ, não ha diferença alguma (sic). O mecanicamente inexplicavel da teoria kantesca quer dizer em linguagem monistica: a parte de sentimento que o movimento não explica. Vê-se pois que KANT não foi, nem podia ser um dualista." (35)

E, assim, transformando KANT em um monista, julgava o nosso pensador poder antever as bases do que ele chamava a "filosofia critica do futuro".

A figura de KANT exercia tamanha sedução sobre os espiritos da corrente, que CARLos de LAET denominou ironicamente "Escola teuto-sergipana", que os seus adeptos jamais quizeram reconhecer quanto estavam divorciados do criticismo.

O caso de Silvo Romero é tipico, porquanto assinala todo um processo espiritual de fidelidade a KANT, não obstante a variação de outras influencias sofridas por sua inteligencia irrequieta.

Já em 1878, publicando o opuscula "A Filosofia no Brasil", o historiador de nossa literatura fazia questão de assim se pronunciar:

(34) Tobias Barreto, op. cit., pg. 46.

(35) Tobias Barreto, op. cit., pg. 47. 
"O meu sistema filosofico reduz-se a não ter sistema. algum porque um sistema prende e comprime sempre a verdade.

"Sectario convicto do positivismo de Comte, não na direção que este lhe deu nos ultimos anos de sua vida, mas na ramificação capitaneada por EMILE LITTRÉ, depois que travei conhecimento com o transformismo de DARWIN, procuro harmonizar os dois sistemas num criticismo amplo e fecundo.

"Nem é isto alguma novidade exquisita, quando a tendencia filosofica principal na Alemanha, Inglaterra, França, Italia e Espanha na atualidade é justamente este criticismo independente, firmado nos dados positivos, especie de neokantismo (sic), não por ir pedir ideias a KANT, mas por tomar-lhe o espirito. Neste sentido o moderno "Ess muss auf KANT zurückgegangen werden" é verdadeiro." (36)

Lembra, então, Silvio Romero que esse néo-criticismo é a filosofia dos mais altos espiritos da 'Alemanha, da França e da Inglaterra, reunindo celebres naturalistas como HeLmholtz e Du Bors-Reymond, Huxley, Týndall.

Eis aí a constante da Escola: conciliar sempre KANT com os mais conspicuos e "atuais" resultados das ciencias, com aquilo que parecia ser mais "moderno", a filosofia da ultima hora.

Quando Silvio Romero abandona Augusto Comte e passa para HaEckel, no convivio calido de Tobias Barreto, ainda não se afasta de KANT, como deste não se afastará ao encontrar a sua posição definitiva no "evolucionismo spenceriano", de que se fez ardoroso batalhador, especialmente em "Doutrina contra Doutrina", paginas oandentes escritas contra a seita de Augusto Comte e Clotilde de Vaux.

E na I I Parte do Ensaio de Filosofia do Direito, cuja 1. ${ }^{\text {a }}$ edição é de 1895 e a 2.a de 1907, que encontramos a tentativa de conciliação entre KANT e SPENcER.

(36) Silvio Romero, A Filosofia no Brasil, Porto Alegre, 1878, pgs. 183-184. 
Após reivindicar no prefacio dessa obra a gloria de ter sido o primeiro a citar Ihering no Brasil (1875) e a empregar o termo "monismo" (1876), _ dados de grande alcance para a determinação da mentalidade da epoca, sofrega da "ultima verdade", - o escritor sergipano revela mais uma vez o seu apreço às ideias kantianas, passando a "caracterizar o moderno espirito em filosofia", que lhe parece dever ser "mono-evolutiva", "critica", "subordinada às ciencias particulares" e formada de processos a posteriori, com desprezo, o mais possivel (sic) dos velhos metodos a priori".

Depois de enumerar os varios sistemas filosoficos, declara Romero: "a seu lado levanta-se o criticismo realista, ou naturalismo critico, ou evolucionismo agnostico, inaugurado por IMANUEL KANT, a primeira organização filosofica de todos os tempos."

Segundo Silvio, o estudo aprofundado do filosofo indica, positivamente, que ele domina o pensamento moderno nas principais correntes de suas ideias. Assim, em filosofia geral, o agnosticismo, tão esplendidamente aceito e desenvolvido por Herbert Spencer e tomado da Critica da Razão Pura, é lei predominante. Em estetica, o principio adotado pelo darwinismo e por toda a escola evolucionista, de ser o belo um livre brinco de nossa imaginação e de nosso entendimento, é um ponto de vista aprendido na Critica a bo Juizo. (54-55)

Eis aí como tudo se harmoniza como por encanto: não ha principio fundamental da corrente evolucionista que não possa remontar às fontes sempre novas do solitario mestre germanico.

Não podemos, pois, concordar com Clovis quando nos apresenta Tobias e Romero sem ligar suas "doutrinas" à de

(97) Silvio Romero. Ensaio de Fil. do Direito, 2.a ed., pgis. 34 a 54. Para facilidade de leitura, indicaremos no texto as paginas a que fizermos referência, procurando reproduzir os proprios termos empregados pelo Autor. 
KANT: O segundo daqueles escritores sergipanos, sempre dado a profissões de fé, não deixa duvidas sôbre sua posição. Destaquemos esta declaração peremptoria:

"O naturalismo evolucionista hodierno, posto ao par da ciencia corrente, é, em nosso modo de pensar, em suas linhas capitais, o kantismo rejuvenescido pelo orgão de SPENCER." (56)

Não vamos aqui reproduzir e apreciar a doutrina de Silvio Romero, notadamente nos pontos em que ele se afasta de Tobias Barreto, sustentando o carater cientifico da sociologia, mostrando a contradição entre o seu semi-mecanismo e o semi-teleologismo, combatendo a doutrina do direito como politica da força, e precisando o conceito de cultura; do contrario fugiriamos do objeto deste trabalno. As divergencias entre ToBias, Silvio $e$ Clovis a proposito da concepção do Direito como um fenomeno cultural constituem um dos raros momentos de fecunda indagação filosófico-juridica em nossas letras; a essa questão esperamos volver em outra oportunidade.

O que desejamos mostrar agora é apenas a posição dos dois pensadores sergipanos em face de Kant. Embora monista um e evolucionista o outro, ambos formam talvés a linha da heterodoxia kantiana no Brasil, no sentido de um "naturalismo critico", ou de um "neo-criticismo evolucionista”, para empregarmos expressões caracteristicas de Sruvıo Romero. (38)

Passando ao campo especial da Filosofia do Direito, é ainda a ascendencia kantiana que se nos depara, tanto na obra de ToBias, como na de Silvio, maximé quanto à determinação conceitual do Direito. Sempre explicito, o segundo escreve:

(38) Não foi apenas entre nós que esse fenomeno se verificou. o positivismo critico de IcILIo VANNI, aliás posterior ao dos nossos pensadores, é bastante significativo. Cfr. VANI, Lezioni di Filosofia del Diritto. 
"Importa dizer que a definição que vamos propor é, no fundo, a de KANT (sic), revigorada, enlarguecida pela doutrina de SPENCER.

"Kant doutrinou: "Direito é o complexo das condições. que limitam as liberdades para tornar possivel o seu acordo". Temos aí uma definição lacunosa que substituiremos por esta: "Direito é o complexo das condições, criadas pelo espirito das varias épocas, que servem para, limitando o conflito das liberdades, tornar possivel a co-existencia social." (39)

Depois de dar essa definição, - que representa uma translação da "conđicionalidade" logico-categorial de KANT para o plano empirico da condicionalidade hïstorico-social, - Silvio Romero não esconde a sua satisfação por ver juntos, entrelaçados, os seus dois idolos:

"E, dess'arte, exclama êle, o conceito da evolução spenceriana fecunda a doutrina kantesca e a confunde com a verdade mesma. Temos, assim, mais uma vez, otimo ensejo de confirmar nossa velha opinião de que o spencerismo naquilo que êle tem de essencial e duradouro é uma especie de neo-critismo, de neo-kantismo, rejuvesnecido e alargado. E um só e mesmo sistema nas linhas fundamentais." (40)

\section{O kantismo do Conselheiro Lafayette}

Quem não viu com bons olhos o conubio de Kant com Spencer foi uma das mais lucidas expressões de nossa Jurisprudencia, o Conselheiro Lafayette Rodrigues Pereira.

(39) Silvio Romero, Ensaio de Filosofia do Direito, Rio, 1908, 2.a ed., pg. 275.

(40) Silvio Romero, op. cit. pg. 275. Vem a talho a lembranca de que a noção de Direito de SPENCER corresponde efetivamente à de Kant. E sabido que, notada essa correspondencia por MaItLand, o filosofo inglês alegou ter chegado a conclusōes analogas sem ter lido a obra de KalNT sôbre o Direito mas que não é possivel confun- 
Espirito subtil, dotado de uma mordacidade forrada de cultura humanistica, o jurisconsulto mineiro, que é um filho espiritual da Faculdade de Direito de São Paulo, saiu a campo para defender dois solitarios: MAchado DE Assis e KaNT.

Conta Carlos Süssekind de Mendonça que o motivo real do inopinado ataque de LAFAyetTe contra Romero, condensado nas paginas vivas de Vindiciae, foi um antigo ressentimento, por ter o critico sergipano, sob o pseudonimo de "Feuerbach", desferido em 1879 cutiladas maldosas contra a nobre figura do parlamentar e jurisconsulto.

Fazendo um paralelo de Lafayette com José Bonifacio, o Moço, o irreverente Romero entre outras cousas escrevera:

"Se o celebre lente de S. Paulo é, no dizer do seu proprio adversario, como o condor, que se remonta às mais elevadas eminencias do pensamento, ao mediocre sr. LAFAYETTE está reservado, quando muito, a figura do gavião, que é uma paródia da aguia. Seu vôo não é largo. É o mais perfeito tipo do legista modorrento, paciente e ledor, que procura trajar as roupagens do tempo, mas que, sob as douraduras da época, encobre o busto de um Lobão ou outro qualquer mofento jurista luso. Já chegado à velhice, pouco tem produzido de realmente serio. Desafiamos a qualquer de seus encomiastas que nos apresente uma só ideia, uma só doutrina original, ou ao menos proveitosa, oriunda das meditações do nosso autor. Ele é mais um compilador, um alfarrabista juridico, do que um jurisconsulto. Não tem filosofia para animar os seus trabalhos. Não tem sistema, nem alto senso critico." ( . .) "O Sr. Lafayette não é um filosofo do direito, cujos dogmas juridicos se elevem à altura de principios. ." (41)

di-las, dada a diferença essencial de indole e metodo (cf. o Apendice $A$ ao livro de SPENCER sobre a Justiça).

(41) Apud C. Sussekind de Mendonç, Silvio Romero, Brasiliana, 1938, pg. 219/220. A 1." edição ‘de "Vindiciae" é de 1899, mas consta de artigos, escritos anos antes para o "Jornal do Comércio". 
Como os artigos de Vindiciae foram escritos 15 anos após o ataque de Silvio, a afirmação do biografo deste não passa de uma conjetura.

O certo é que, sob o pseudonimo de Labieno, o conselheiro aprecia a obra de Romero como critico e filosofo. MACHAdo DE Assis não poderia pretender defensor mais penetrante e sagaz de seus valores esteticos e literarios. 0 escrito de LAFAYETTE é uma lição de bom gosto, onde se maneja o florete da ironia com uma elegancia rara em nossas letras, revelando a afinidade do seu espirito com o do cetico humanista de $D$. Casmurro.

Como bom tático, LAFAYETTE, após a defeza do mestre de nosso romance, desfecha um ataque frontal à filosofia de Silvio Romero condensada nos "Ensaios de Filosofia do Direito", publicados em 1895. Bela oportunidade que se oferecia ao jurista para demonstrar que não era o roedor de alfarrabios, destituido de cultura filosofica.

Aquela acusação de Silvio deveria ter pesado no espirito de LAFAYETTE, que, desde os bancos academicos, entre 1858 e 1857, revelara pendor pelas cogitações metafisicas, sendo presidente efetivo do "Ensaio Filosofico", de cuja revista havia sido colaborador conspicuo.

Desde então se firmara a sua predileção pela doutrina de KANT, que ia agora defender, revelando uma compreensão mais exata da filosofia critica, como talvez só se encontre no Brasil nas paginas de Farias Brito e no ensaio que o antigo Prof. de Filosofia do Direito de Porto Alegre, Lucas GAFFrÉE, dedicou à "Teoria do Conhecimento de KANT" em 1909. (42)

(42) Embora se trate de uma simples exposição da teoria kantiana, o mestre gaucho externa aqui e ali os seus pontos de vista, que revelam suas simpatias pelo criticismo e a sua convicção de que "todo moderno sistema filosofico é obrigado a girar em torno das bases, firmadas por KANT, e aceitando-as ou mesmo combatendo-as, a tomá-las como ponto de partida para as construções que houver de levantar." (op. cit., pag. 3). 
O kantismo de LAFAyETTE, a que alguns autores fazem sumaria referencia (43), ainda não foi, ao que nos parece, objeto de uma analise mais aprofundada: constitue uma posição filosofica que não só se afeiçoa ao seu feitio de humanista cético, como se alicerça em clara apreensão dos motivos essenciais do criticismo transcendental.

Na critica ao ensaio de Silvio Romero, a aceitação do criticismo em seus valores essenciais permite-nos apresentar a LAFAYETTE como um kantista mais coerente, embora ainda preso a certos pressupostos jusnaturalistas.

Circunscrevendo a apreciação de "Vindiciae" tão somente à parte relativa ao combate ao "neo-criticismo evolucionista", podemos dizer que o trabalho de LAFAYETTE, ao mesmo tempo que desarticula o conubio kant-spenceriano, tem o cuidado de repôr as ideias do filosofo alemão em suas matrizes originais e puras.

"Com a honesta pretensão de pôr o seu monismo sob a imponente autoridade do maior genio da. Filosofia, o sr. Romero escreve, e mais de uma vez o repete, com adoravel candura - que KANT é monista! E outra afirmativa de inconsciente. Na Crïtica, da Razão Pura, Kant traçou uma linha de separação, que ainda niguem poude transpor, entre o entendimento, mundo interno, e o não-eu, noumenon, o mundo externo. Eis aŕ o dualismo." (44)

LAFAYETTE não compreende como se possa conciliar SPEncer e KANT, a não ser "por uma santa inocencia", pois

(43) Nesse sentido, lembramos, por exemplo, afirmação de ANDrade e Silva no artigo sobre Lafayette inserto na "Revista Forense" vol. C, pg. 175 e as palavras encomiasticas de Oliveira Torres em sua obra sobre "O Positivismo no Brasil”, cit., pg. 219, onde se insere, aliás, uma conclusão um tanto apressada sobre a difusão do kantismo entre os nossos juristas. LAFAYETTE formara-se, em verdade, naquele clima espiritualista reinante na Academia de S. Paulo a que já nos referimos.

(44) Como se vê, Lafayetre interpreta a "cousa em si" em sentido realista, identificado, aliás, imprecisamente, o "noumenon" com o "mundo externo". De qualquer forma, êle viu bem o equi- 
a filosofia do primeiro e o sistema filosofico do segundo são "radicalmente diferentes nos fundamentos, nos processos e nos resultados." (pg. 72).

Se para Kant o espaço e o tempo são as formas virtuais da sensibilidade, puras formas do espirito a que não corresponde nenhuma realidade objetiva, segundo Spencer o espaço tem uma realidade objetiva e o tempo não é senão uma ideia de relação, sendo ambos conceitos adquiridos por meio da experiencia. (72)

Para Kant, o entendimento só conhece os fenomenos, como eles the aparecem e segundo as leis do proprio entendimento, ao passo que para SPENCER as leis do entendimento não são senão formás impressas no espirito pelas sensações repetidas e transmitidas por atavismo. (73-74)

Para Kant o mundo dos fenomenos é uma pura idealidade; para SPencer é uma realidade objetiva.

KANT considera o bem, o dever, o direito, o justo como conceitos de razão, conceitos a priori. SPENcEr sustenta que todas estas noções não são senão ideias que têm sua origem nos fatos e, portanto, meros conceitos experimentais. (74)

Daí a conclusão logica inexoravel: as duas filosofias não são simplesmente diferentes, mas uma é, por assim dizer, a negação da outra.

LAFAYETTE inflama-se e declara que Kant é uma vitima da ignorancia do sr. Romero, que não poude compreender "a analise a mais, penetrante, a mais profunda e a mais completa que jamais filosofo fez das faculdades do espirito humano." (75)

Depois de uma critica percuciente de outros pontos frageis do "sistema" de Silvo Romero, o jurisconsulto volta a sua atenção para os dominios juridicos, mais uma vez revelando a insubsistencia do empirismo do pensador sergipano,

voco de Tobias e Romero em apontar KANT como um monista, equivoco só comparavel ao de Preno Lessa que tambem incluiu o filosofo de Koenigsberg entre os deterministas para prestigio de sua tese contra o livre arbitrio. (Cf. op. cit., pg. 188). Indicamos, a seguir, no texto, as paginas de Vindiciae entre parentesis. 
não obstante a roupagem emprestada do criticismo transcendental.

E na analise do "conceito do direito" e da "ideia do justo" que se revela mais claramente o kantismo de LAFAYETTE circunscrito aos moldes dos "Elementos da Metafisica do Direito", obra que, como dissemos, ainda alberga motivos do jusnaturalismo dominante no seculo XVIII. A posição de LAfAYETTE no plano da Jurisprudencia corresponde, em linhas gerais, à de Thibaut, que, embora sofrendo forte influxo do criticismo, não se separou de certas ideias mestras da Escola do Direito Natural.

Vale a pena examinar as colocações juridicas fundamentais do jurista que Silvio Romeno julgara destituido de formação filosofica.

Uma das afirmações fundamentais do neo-kantismo juridico (referimo-nos ao autentico. ) é a de que, depois de KANT, ficou evidenciado que não é possivel a determinação do "direito" e do "justo" mediante processos indutivos, ou seja, tão sómente com elementos da experiencia.

Em primeiro lugar, escrevem Stammler e Del Vecchio em obrás que se tornaram classicas (45), a experiencia só nos dá o que é particular e transitorio, ou seja, aquilo que é essencialmente historico, ao passo que o que se deseja alcançar é um conceito de Direito e uma ideia de justiça de carater universal, suscetivel de aplicar-se tanto à experiencia juridica do passado como à do presente e do futuro. Devemos, portanto, ter uma noção de juridicidade distinta das variações de seu conteudo e superior a elas.

Em segundo lugar, mesmo que a experiencia pudesse ser o unico ponto de partida para a formaşãa de ideias uni-

(45) Sobre as afirmações fundamentais do neo-kantismo de STAMmLer e Del Vecchio, e respectiva bibliografia, consultar nossa tese Fundamentos do Direito, S. Paulo, 1940, cap. I. 
versais, ver-nos-iamos em um verdadeiro circulo vicioso: si ainda buscamos determinar o conceito do Direito, como é que consideramos juridica determinada relação social?

Os empiricos, dess'arte, no momento em que tomam certo fato como juridico, já estão dando como resolvido aquilo mesmo que lhes cumpria resolver.. "A observação dos dados empiricos, lembra DeL Vecchıo, não pode conduzir por si só à determinação do conceito formal do Direito, porque ela pressupõe esse conceito. Quando empreendemos o exame dos dados historicos em geral e queremos discernir entre eles os dados juridicos, confiamos numa certa noção, que está incluida em nosso espirito e que permite distinguir o que é juridico e o que não o é, o que pertence à logica do Direito e o que dela se exclui. o criterio distintivo é, por conseguinte, logicamente anterior à observação." (46)

Finalmente, mesmo na hipotese de se obterem os conceitos do Direito e do Justo como mero resultado de um trabalho de abstração, estaria resolvido o problema do conhecimento do Direito, mas nunca o do dever juridico, visto como de um "ser" jamais resulta um "dever ser", um indicativo não se pode converter em um imperativo: "nous ne pouvons pas trouver, esclarece Boutroux na sua penetrante análise da doutrina kantiana, dans la simple constatation. de ce qui est, l'indication de ce qui doit être." (47)

Assim sendo, o conceito de Direito deve ser "a priori" e o dever juridico só pode se fundamentar na auto-consciencia das personalidades, postulado pela liberdade de cada. individuo como condição da vida etica.

o Direito é, pois, uma condicionalidade logica de arbítrios, uma ordenação coercivel assente sobre o pressuposto puramente eidético de um "contrato social" concluido entre seres livres segundo uma lei univensal de liberdade. $£$ pela ideia pura do justo que se põe o "conceito" de Direito.

(46) Vide Dex Vecchio, Filosofia del Derecho, cit., pg. 85.

(47) Boutroux, La philosophie de Kant, Paris, 1926 pg. 295. 
Eis aí, em uma sintese acanhada, o nucleo essencial do neo-kantismo juridico contemporaneo, contraposto às pre-tensões das doutrinas empiricas.

Pois bem, essas teses, que Stammler e Del Vecchio de senvolveram no fim do seculo passado e no inicio deste, já as encontramos claramente formuladas no escrito pole-mico de nosso conselheiro LAFAYETTE.

Eram posições, em verdade, inerentes ao kantismo, mas: só o fato de as encontrarmos fixadas em escritos polemicos: de 1894-95 revela a plena consciencia doutrinaria de seu autor.

Para que se possa fazer um cotejo entre as afirmações. neo-kantistas e as observações do jurisconsulto, vamos reproduzir alguns trechos mais expressivos de "Vindiciae", pondo em realce a sua correlação com as teses acima discriminadas.

Quanto à impossibilidade de se atingirem os conceitos do "Direito" e do "Justo" mediante simples dados empiricos, escreve LAFAYETTE:

“A consequencia, pois, invencivel, inelutavel é que os: principios necessarios e universais não são verdades experimentais. Esses principios são leis proprias da constituição do espirito, são dados da razão ( . . ). O principio do direito - o justo - tem os caracteres dos principios da razão - é universal e imutavel. O justo é sempre o justo, debaixo de quaisquer circunstancias, em todas as latitudes, em todos os tempos."

"A universalidade e a imutabilidade do principio excluem o elemento empirico, porque o elemento empirico é perpetuamente variavel, dá o geral, mas não dá o absoluto, isto é, o que não sofre exceções.

"A indução nunca poderia tirar de um fato a ideia do justo. $\mathrm{O}$ fato em sua materialidade não é justo nem injusto. $O$ mesmo fato tomado em si pode ser o exercicio, pode ser a violação do direito. Corto uma arvore no meu campo; 
exerço um direito. Corto uma arvore no campo do vizinho; violo um direito. Multipliquem-se, como quizerem os fatos. A analise não descobre neles o justo." (48)

Sobre o carater regulativo do "justo" como ideia pura anterior à experiencia, LAFAYETTE pondera:

"A ideia do justo não provém, nem pode provir do fato e de suas relações. É necesariamente uma ideia dada pela razão. Se o espirito não tivesse a ideia do direito preexistente, lhe fora impossivel julgar se um fato ocorrido era ou não justo. A qualificação de justo pressupõe uma regra, um principio superior, que não está no fato, que não pode ser tirado do fato, mas a que o fato é subordinado.

"Existe, portanto, fóra de toda contestação, um principio puro, uma norma de direito, a priori, que envolve afinal o elemento empirico, mas que é dele essencialmente distinta." (49)

Quanto à ideia kantiana de que o homem deve sempre ser tratado como um fim e que a liberdade é o principio do Direito, escreve ainda LAFAYETTE:

-"A liberdade é o elemento constitutivo da personalidade. O homem é pessoa porque é fim de si mesmo; é fim de si mesmo porque é livre; se pudesse ser convertido em meio, sseria escravo e não livre.

"A liberdade, como diz Kant, dá pelo principio de contradição, o díreito. Seria contraditorio que o homem tivesse liberdade e não tivesse direitos."' (50)

Depois de demonstrar que Silvio Romero confunde a Filosofia do Direito Positivo com a Filosofia do Direito, o conselheiro fixa, expressamente, as suas convicções kantiaanas, dizendo:

"Antes de Kant nenhum filosofo ou jurisconsulto tinha ferido clara e diretamente a verdadeira caracteristica do

(48) Lafayette, Vindiciae, op. cit., pg. 129.

(49) Op. cit., pg. 130.

(50) Lafayette, op. cit., pg. 131. 
direito. O direito só aparece quando o homem entra em contacto com o seu semelhante. A convivencia seria impossivel, ou seria a lúta perpetua, sem um principio que circumscrevesse a liberdade de cada um. E esse principio, que torna possivel a coexistencia, é o direito no sentido objetivo. O direito faculdade é o poder de atuar dentro dos limites traçados pelo direito principio. $\mathrm{E}$ que Kant acentuou com uma nota firme, dizendo que o direito é o que torna possivel "o acordo da liberdade 'de todos com a liberdade de cada um." (51)

Finalmente, o autor de "Direitos de Familia", após tentar demonstrar que a definição kantiana do Direito não é puramente negativa, mas, ao oontrario, "dotada do conteudo positivo da ideia do Direito", passa a examinar a definição substitutiva de Silvio Romero.

Só mesmo um espirito plenamente integrado no criticismo paderia ir diretamente à raiz do problema, revelando a alteração essencial introduzida na determinação kantiana da juridicidade pelo empirismo.

Em uma frase incisiva, LAFAYETTE nos mostra o diverso emprego da palavra "condição" pelos kantistas e pelos empiristas, aqueles traduzindo um pressuposto logico, estes indicando uma circunstancia empirica:

"Direito, afirma ele, no ponto de vista em que o fazia KaNT, não é um complexo de condições, mas de principios. A condição, elemento empírico, é variavel, e KANT tinha em mente o elemento imutavel, o principio a priori." (144)

Vê-se por aí que LAFAYETTE teve consciencia do processo historico de translação do conceito de condicionalidade, do plano lógico-categorial em que o colocara KANT, - entendido como pressuposto transcendental de conhecimento da experiencia juridica - para o plano empirico-social, entendido como complexo de circumstancias contingentes condicionadoras da vida e do progresso sociais.

(51) Lafayette, op. cit., pg. 143. 
Depois da definição puramente logico-contratual de Kant, que Silvio Romero mutila na citação supra transcrita, temos a definição de Krause, onde a ideia de condicionalidade já adquire elementos empiricos: "das Recht ist das. organische Ganze der von der Freiheit abhängigen Bedingungen der organischen Ganzen des Vernunft leben." (52)

Essa ideia do Direito como totalidade organica das condições dependentes da liberdade para o alcance harmonico do proprio destino, se por um lado supera o individualismo de KANT, introduz no conceito de "condicionalidade" algo de empirico, "como principio organico regulador, destinado a manter a harmonia e a saude do corpo social". (53)

Desse conceito passamos a IHERING e já então os elementos empiricos sobrelevam, e a condicionalidade perde sua acepção de categoria logico-normativa para ser algo de concreto ou empirico, como "condição de vida da sociedade": "Recht ist der Inbegriff der mittels aussenren Zwanges durch die Staatsgewalt gesicherten Lebensbedingungen aer Gesellschaft in weitesten Sinnen des Wortes." (54)

As conhecidas definições de Gumercindo Bessa, Silvio Romero ou Pedro Lessa são meros arranjos pouco felizes de expressões de Ihering e de Krause, juxtapondo-se a ideia de "condições existenciais da sociedade", empregada por um, com a nota de "dependencia da vontade humana" apontada pelo segundo...

LAFAYETTE não podia dar, por certo, o seu apoio a êsses: mosaicos conceituais.

\section{Direito Natural e Direito Positivo na concepção de Lafayette}

As paginas anteriores revelam como foi excessivo Clovis Bevilaqua na quasi exclusão de Kant de nossa pobre

(52) Krause, Das System der Rechtsphilosophie, Leipzig, 1874, pagina 62 .

(53) Cf. Ahrens, op. cit., Leipzig, 1875, pg. 136.

(54) Iherdng, Der Zweck im Recht, I, pg. 434, Leipzig, 1877. 
cultura filosofica, e, mais ainda, quando olvidou a posıção nitida de LAFAYETTE.

Dir-se-á, entretanto, que esse kantismo do jurisconsulto montanhês, que os nossos vizinhos apresentam como prototipo de sua mentalidade serena e aguda (55) não passou de um porfico elegante, sem ressonancias no interior do edificio juridico, sem reflexos na obra logico-dogmatica do civilista ou do internacionalista.

Não nos parece que assim seja.

Se Cliovis Beviladua sempre revelou em sua obra de jurisconsulto as suas convicções de naturalista spenceriano movido pelo sopro etico de IHERIng; se Joño Mendes Junior se manteve um escolastico no cơnteudo e na forma expressional de seu pensamento juridico; se Teixeira de Freitas revelou sempre sua fidelidade ao modelo savignyano de jurista integrado na plenitude da experiencia do Direito; não será desarrazoado dizer-se que LAFAYETTE demonstra seus principios kantianos na realização de sua obra jurisprudencial.

Não obstante a visivel influencia de ideias comuns a todos os espiritualistas da epoca, ha algo em seu conceito de Direito Natural que denota o signo de KANT, para quem o justo era sobretudo um principio valorativo, uma pedra de toque ou de aferição ("Probierstein" ou "Masstab", como dizia o filosofo.) (56)

Segundo LafayetTe, o Direito Natunal, não é propriamente uma duplicata ideal do Direito Positivo, embora seja sc o principio regulador do Direito Positivo, o ideal para o qual ele tende sempre e do qual tanto mais se aproxima quanto mais se aperfeiçoa." (Vlindiciate, pg. 133).

O direito Positivo, esclarece êle, é uma "especie de materia plastica destinada a acomodar o Direito Natural à vida

(55) Vide nesse sentido os pronunciamentos de MrLton Campos, Edmundo Lins e Teixeira Salles em "Rev. Forense, Vol. LXII, pg. 289 e seg.

(56) Sobre o jusnaturalismo de Kavr e o inicio do Direito Racional, vide nosso estudo citado sobre "O Contratualismo", nesta revista. 
pratica tal como ela é." (133) "O Direito carece de passar da esfera ideal para o real, porque ele é de sua natureza. pratico; é preciso que ele se determine e se concretize. 0 Direito determina-se, concretiza-se pelo fato, pela intervenção do elemento empirico." (132)

Eis aí afirmações que demonstram que LAFAYETTE se. mantem apegado aos "Elementos metafisicos da Ciencia do Direito", que os neo-kantistas atuais consideram pouco consequente em face das conclusões da "Critica da Razão Pura", e, ao mesmo tempo, presta tributo aos principios consagrados pelo "krausismo hiberico."

E por isso que dizemos que a posição de LAfayerte corresponde até certo ponto à de Thibaut. Si este concebe: - Direito Natural como um sistema juridico completo que vai se realizando no plano historico (donde a necessidade da aplicação do metodo historico), o jurista patrio segue: uma via intermedia, buscando uma conciliação, bem pouco precisa, entre o Direito, como ideal a que a positividade tende (influencia dos espiritualistas da metade do seculo. passado) e o Direito como "principio regulador" ou pura ideia de razão à maneira de KANT.

Foi essa posição intermedia que impediu a LAFAYETTE: reconhecer que só na ideia de "cultura", esboçada na obra de Silvio Romero e Tobias Barreto, seria possivel encontrar a explicação dialetica da concretização dos valores do justo como experiencia historica. $O$ ardor polemico não era, aliás, propicio para se vislumbrarem acertos na obra dos. adversarios.

As ideias de um Direito Natural ideal-regulativo encontram-se nos livros juridicos do Conselheiro, exercendo função dogmatica digna de menção.

Assim, por exemplo, em seus "Principios de Direito Internacional", publicados em 1902, quinze anos antes de sua morte, declara que "o Direito natural fornece os tipos e os criterios para o trabalho de comparação e critica" das 
normas juridicas, constituindo "uma especie de razão su-perior do Direito Internacional", mas que deve ser concebido como "um direito ideal que a ciencia concebe como uma teoria pura." Refere-se, então, significativamente a. Wolf, Kant, Stahl e Ahrens (vol. I pg. 26 e segs.)

Em "Direitos de Familia", cuja primeira edição é de. 1869 , já se afirmara a tendencia de compor Direito Natural e Positividade, universalidade conceitual e relatividade historica, ou melhor, "razão filosofica" e "razão historica", como ele mesmo diz, afim de, em conjunto tornar orga-. nicamente inteligiveis os textos. (op. cit. pg. XII).

E nesse trabalho que o nọso jurista discorda da classificação do Direito Civil apresentada por TeIXeIra dE FreITAS, para ter sob os olhos a classificação usada na Alemanha e que ele filia a Heise e Thibaut, o que quer dizer, a dois nomes ilustres intimamente ligados ao criticismo kantista. Através, pois, da Dogmatica juridica da epoca, admiravelmente assinalada por LAFAYETTE e outros, KANT tornava-se presente: na estrutura logico-normativa mesma de nossas criações ju- ridicas, sem perda dos elementos originais da experiencia cientifica portuguesa, que Melo FreIre genialmente sistematizara "ao influxo, nota LAFAyETte, das ideias filosoficas do temṕpo e na meditação dos escritos com que a Escola Alemã do. seculo passado (sec. XVIII) iniciara os trabalhos que foram tão brilhantemente continuados por Thibaut, Hugo e. SAvignY". (Direitos ide Familia, prefacio).

E ainda no prefacio de seu primeiro livro que LAFAYETTE, fixà os elementos de sua metodologia juridica, harmonizando, à maneira de Thibaut, o elemento racional e o historico: "A metodologia juridica indica-nos um processo profundamente racional: temos por guia os principios direta ou indiretamente deduzidos das fontes, e o criterio que dá a indole. e o genio do Direito vigente. É a esse toque que devem ser. contrastados os costumes, as praticas forenses, as opiniões. 
* dos escritores e as disposições paralelas dos codigos estrangeiros" (ibidem).

No "Direito das Cousas", publicado pela primeira vez w:em 1877, LAFAyETte revela a mesma fidelidade a KANT, o unico filosofo do Direito que ele invoca em abono de suas teses, ao lado dos mestres da Dogmatica europeia. (57) Significativa, por excessiva, é, aliás, a referencia ao filosofo logo no inicio do prefacio para fixar a necessidade da propriedade "nas condições da vida humana neste mundo que Kant chama fenomenal"...

Em suma, 'foi LAFAYETtE um kantiano que, se não manteve absoluta coerencia em materia juridica com os principios do criticismo, pode invocar o exemplo do proprio KANT, alvo de igual critica.

A doutrina de Kant exerceu, pois, segundo nos parece, uma poderosa influencia em alguns dos nossos espiritos mais brilhantes e ainda hoje conta adeptos de prol, cuja obra não pudemos analisar.

Dos grandes mentores da Filosofia do Direito só HegeL parece não ter tido ressonancia em nossa cultura, hoje em dia percorrida por outras correntes que procuram superar *o individualismo kantista ou o abstratismo racionalista para a compreensão da experiencia juridica na totalidade de seus valores humanos.

São Paulo, Abril-Maio de 1947.

(57) Vide, entre outras citações da Metafisica do Direito, as de pgs. 2 e 166 do I vol. do Direito das Cousas, ou da pg. 54 do II wolume dos Principios do Direito Internacional para fixar a inseparabilidade de direito e "faculdade de coagir". Nem é demais lembrar que já em 1877, no Direito das Cousas, à pg. XII, citava Ihering, dois anos depois do "feito" de Silvio Romero, cuja tese talvez náo' fosse ainda conpecida no Sul. . Não resta duvida que o alfarrabista estava em dia com a cultura da epoca... 